\title{
MODEL PEMBELAJARAN KOOPERATIF TIPE NUMBERED HEAD TOGETHER PADA TEKNIK DASAR PASSING BOLA VOLI
}

\author{
Putu Eka Yogantara, I Putu Panca Adi , I Made Satyawan. \\ Fakultas Olahraga dan Kesehatan \\ Universitas Pendidikan Ganesha \\ email: \{putuekayogantara6@gmail.com,panca.adi@undiksha.com¹, \\ made.satyawan@undiksha.ac.id $\left.{ }^{2}\right\}$
}

\begin{abstract}
Abstrak
Tujuan penelitian ini yaitu untuk mengetahui pengaruh model pembelajaran kooperatif tipe NHT terhadap hasil belajar teknik dasar passing bola voli. Jenis penelitian ini adalah eksperimen semu (quasi eksperimental) dengan menggunakan rancangan penelitian the non randomized control group pretest-posttest design. Subjek penelitian adalah peserta didik kelas XI MIPA dan XI IS SMA PGRI Seririt tahun pelajaran 2019/2020 sebanyak 53 peserta didik. Data hasil belajar dikumpulkan melalui pretest dan posttest. Analisis data menggunakan Uji-t dengan SPSS 16.0 for Windows. Eksperimen dilakukan sebanyak 3 kali perlakuan di luar pretes-posttest. Data hasil belajar dikumpulkan melalui tes objektif, observasi dan unjuk kerja. Pada kelompok eksperimen nilai pretest didapatkan rata-rata nilai 66,48 sedangkan kelompok kontrol 64,0. Hasil nilai posttest pada kelompok eksperimen didapatkan nilai rata-rata 82,76 . Sedangkan Kelompok kontrol didapatkan nilai rata-rata 78,18 . Ratarata gain score normalisasi yang didapatkan pada masing-masing kelompok adalah pada kelompok eksperimen sebesar 0,5 sedangkan kelompok kontrol sebesar 0,4 . Angka signifikansi yang diperoleh sebesar sig 0,001<0,05. Dari hasil penelitian dapat disimpulkan hasil belajar peserta didik yang di berikan perlakuan dengan menggunakan model pembelajaran kooperatif tipe $\mathrm{NHT}$ lebih meningkat dibandingkan dengan kelompok kontrol yang diberikan model pembelajaran konvensional. Model pembelajaran kooperatif tipe NHT berpengaruh signifikan terhadap peningkatan hasil belajar teknik dasar passing bola voli pada peserta didik kelas XI SMA PGRI Seririt.
\end{abstract}

Kata-kata kunci: Model pembelajaran, kooperatif tipe NHT, hasil belajar, passing bola voli

Abstract

The purpose of this study was to determine the effect of the NHT type cooperative learning model on learning outcomes of basic volleyball passing techniques. This type of research is a quasiexperimental (quasi-experimental) research design using the non-randomized control group pretestposttest design. The research subjects were 53 students of class XI MIPA and XI IS SMA PGRI Seririt for the 2019/2020 academic year. Learning outcome data were collected through the pretest and posttest. Data analysis used t-test with SPSS 16.0 for Windows. Experiments were carried out 3 times beyond pretest-posttest treatment. Learning outcome data were collected through objective tests, observation and performance. In the experimental group the pretest score was 66.48, while the control group was 64.0. The results of the posttest score in the experimental group obtained an average value of 82.76. While the control group obtained an average value of 78.18 . The average normalized gain score obtained in each group is in the experimental group of 0.5 while the control group is 0.4 . The significance number obtained is sig $0.001<0.05$. From the research results, it can be concluded that the learning outcomes of students who were given treatment using the NHT type of cooperative learning model were more improved compared to the control group given the conventional learning model. The NHT type cooperative learning model has a significant effect on the improvement of learning outcomes of the basic techniques of volleyball passing in class XI students of SMA PGRI Seririt.

Key words: Learning model, cooperative type NHT, learning outcomes, volleyball passing 


\section{PENDAHULUAN}

Permainan bola voli merupakan salah satu jenis permainan olahraga bola besar yang dimainkan oleh enam orang dalam satu tim. Hal yang harus dikuasai dari permainan bola voli adalah passing atas, passing bawah, servis, smash, dan block. Pada kenyataannya banyak orang yang bisa bermain bola voli namun belum mampu mengusai teknik yag benar. Di SMA PGRI Seririt yang memberikan materi permainan bola voli pada mata pelajaran PJOK dari kelas $X$ hingga kelas XII. Pada observasi awal di SMA PGRI Seririt nilai ketuntasan secara individu pada mata pelajaran PJOK adalah 70. Kelas XI pada tahun ajaran 2019/2020 yang terdiri dari 2 kelas dengan jumlah 53 peserta didik terdiri dari kelas MIPA 25 peserta didik dengan nilai tuntas passing bola voli adalah 9 peserta didik (36\%), sedangkan 16 peserta didik tidak tuntas pada passing bola voli $(68 \%)$. Pada kelas IS dengan jumlah 28 peserta didik (39\%) memiliki nilai tuntas pada passing bola voli sedangkan yang tidak tuntas sebanyak 17 peserta didik (61\%). Secara keseluruhan jumlah peserta didik yang tidak tuntas $(62,26 \%)$ lebih banyak dibandingkan dengan peserta didik yang tuntas $(37,74)$ hal ini berarti mata pelajaran PJOK pada materi passing bola voli di SMA PGRI Seririt belum mencapai ketuntasan belajar. Hal yang menjadi permasalahan adalah model pembelajaran yang bersifat konvensional atau tradisional. Pembelajaran yang monoton cenderung membuat peserta didik merasa bosan dalam kegiatan pembelajaran dan kurangnya partisipasi atau keaktifan peserta didik ketika kegiatan pembelajaran.

Menurut Trianto (2007: 62), "model pembelajaran kooperatif tipe $\mathrm{NHT}$ atau penomoran berpikir bersama merupakan jenis pembelajaran kooperatif yang dirancang untuk mempengaruhi pola interaksi siswa dan sebagai alternatif terhadap struktur kelas tradisional". Model pembelajaran ini, siswa akan dibagi dalam kelompok yang beranggotakan 3-5 peserta didik dan setiap anggota kelompok diberi nomor 1-5, kemudian guru PJOK mengajukan pertanyaan kepada siswa yang nantinya siswa berpikir bersama untuk menyatukan pendapat terhadap jawaban atas pertanyaan yang diberikan dan meyakinkan tiap anggota kelompoknya untuk mengetahui jawaban itu, setelah itu guru penjasorkes memanggil satu nomor tertentu, kemudian siswa yang nomornya sesuai mengancungkan tangannya dan mencoba untuk menjawab pertanyaan untuk seluruh kelas. Adapun kelebihan dari pembelajaran korperatif tipe NHT adalah 1. Setiap peserta didik mejadi siap belajar 2 . Peserta didik dapat melakukan diskusi dengan sungguh-sungguh 3 . Peserta didik yang pandai dapat mengajarkan yang kurang pandai.

Penggunaan model pembelajaran koperatif NHT diperkuat dengan penelitian dari I Komang Ari Darmika yang meneliti pengaruh penerapan model pembelajaran kooperatif tipe numbered head together terhadap hasil belajar teknik dasar passing bola voli terhadap hasil belajar siswa kelas VII SMP Negeri 3 Singaraja tahun pelajaran 2016/2017 menemukan hasil belajar yang signifikan antara siswa kelas VII yang diajar dengan metode ceramah (kelas kontrol) dengan hasil belajar siswa kelas VII yang di ajar. Pada penelitian yang lain terdapat juga Kadek Satriawan meneliti pengaruh penerapan model pembelajaran kooperatif tipe Numbered Head Together terhadap hasil belajar teknik dasar passing bola voli terhadap hasil belajar siswa kelas X SMA Laboratorium Undiksha Singaraja tahun pelajaran 2016/2017 menemukan hasil belajar yang signifikan anatara siswa kelas $X$ yang diajar dengan metode ceramah (kelas control) dengan hasil belajar siswa kelas $X$ yang di ajar.

Berdasarkan permasalahan di atas, maka peneliti akan mencoba melakukan penelitian dengan judul "Pengaruh Model Pembelajaran Kooperatif Tipe Numbered Head Together (NHT) Terhadap Hasil Belajar Teknik Dasar Passing Bola Voli Pada Peserta Didik Kelas XI SMA PGRI Seririt Tahun Pelajaran 2019/2020".

Tujuan penelitian ini adalah untuk mengetahui pengaruh model pembelajaran kooperatif tipe NHT terhadap hasil belajar teknik dasar passing bola voli pada peserta 
didik kelas XI SMA PGRI Seririt tahun pelajaran 2019/2020.

\section{METODE PENELITIAN}

Jenis penelitian yang di gunakan dalam penelitian ini adalah eksperimen semu (quasi experimental). Rancangan pada penelitian ini adalah rancangan the nonrandomized control group pretes posttest design.

Subjek diambil dari kelas XI SMA PGRI Seririt yaitu kelas XI MIPA sebagai kelompok perlakuan dan kelas XI IS sebagai kelompok kontrol. Jumlah keseluruhan sampel yang digunakan sebanyak 53 peserta didik.

Prosedur pengumpulan data di lakukan dengan memberikan pretest sebelum perlakuan dan posttest setelah perlakuan. Adapun bentuk asesmen yang di gunakan adalah dengan menggunakan format pengamatan sesuai dengan aspek yang di amati dalam pembelajaran teknik dasar passing atas dan passing bawah bola voli.

\section{HASIL DAN PEMBAHASAN}

\section{A. Deskripsi Data}

Data hasil belajar pjok peserta didik di peroleh dari hasil pre-test dan post-test yang di berikan kepada kedua kelompok sampel Rangkuman analisis data hasil belajar pendidikan jasmani olahraga dan kesehatan peserta didik pada kedua sampel dapat di lihat pada Tabel 1.

Tabel 1

Rangkuman Analisis Nilai Hasil Belajar Teknik Dasar Passing Bola Voli

\begin{tabular}{|c|c|c|c|}
\hline \multirow{2}{*}{ No } & \multirow{2}{*}{ Variabel } & \multicolumn{2}{|c|}{ Kelompok Sampel } \\
\hline & & Eksperimen & Kontrol \\
\hline 1. & $\begin{array}{l}\text { Jumlah Peserta } \\
\text { Didik }\end{array}$ & 25 & 28 \\
\hline 2. & Rata-rata nilai & 0,5 & 0,4 \\
\hline 3. & Standar Deviasi & 0,014 & 0,027 \\
\hline
\end{tabular}

Berdasarkan tabel 1 tentang hasil belajar passing bola voli kelompok eksperimen dan kelompok kontrol dengan jumlah masing-masing kelas 25 peserta didik dan 28 peserta didik di peroleh ratarata nilai kelompok eksperimen 0,5, sedangkan kelompok kontrol 0,4 dengan standar deviasi pada kelompok eksperimen 0,014 dan kelompok kontrol 0,027.

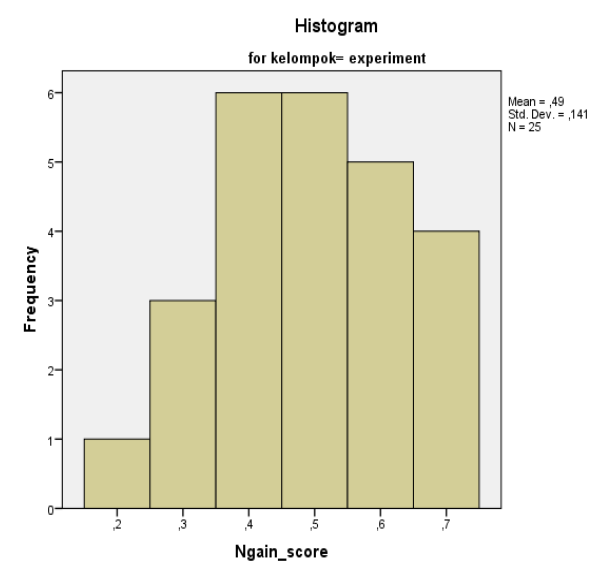

Gambar 1

Grafik Nilai Kelas Eksperimen
Histogram kelas eksperimen di atas menunjukan bahwa data kelas eksperimen berdistribusi normal. Dapat di lihat dari bentuk kurva yang simetris $x=\mu$. Dengan rata-rata 0,5 setelah dihitung dengan gainskor.

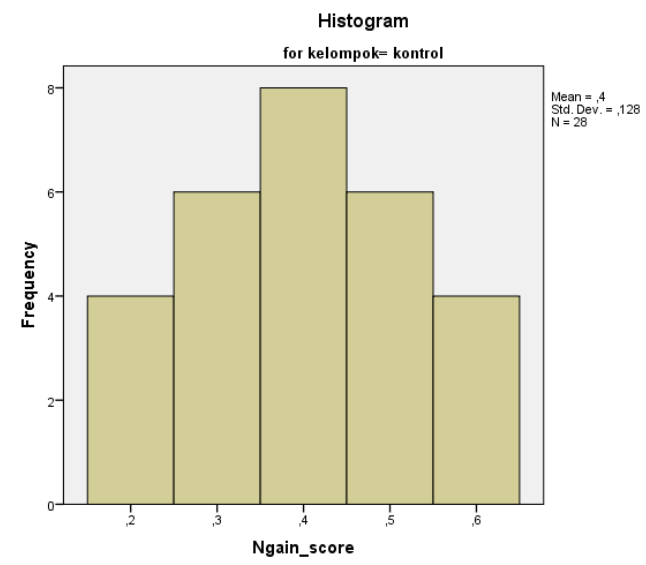

Gambar 2

Grafik Nilai Kelas Kontrol 
Histogram kelas kontrol di atas menunjukan bahwa data kelas kontrol berdistribusi normal. Dapat di lihat dari bentuk kurva yang simetris $x=\mu$. Dengan rata-rata 0,21 setelah dihitung dengan gainskor.

Berdasarkan gambar 4.1 dan 4.2 di atas menunjukan bahwa rata-rata nilai hasil belajar kelas eksperimen lebih tinggi di bandingkan dengan kelas kontrol.

\section{B. Pengujian Hipotesis Penelitian \\ 1. Uji Normalitas}

Jika $p>0,05$ data berdistribusi normal, sebaliknya jika $p<0,05$ data tidak berdistribusi normal.

Tabel 2

Hasil Uji Normalitas Sebaran Data

\begin{tabular}{lccc}
\hline \multirow{2}{*}{ Kelas } & \multicolumn{3}{c}{ Kolmogorov-Smirnov $^{\mathbf{a}}$} \\
\cline { 2 - 4 } & Statistic & Df & Sig. \\
\hline $\begin{array}{l}\text { gain score kelas } \\
\text { eksperimen }\end{array}$ & .103 & 32 & $.200^{*}$ \\
\hline $\begin{array}{l}\text { gain score kelas } \\
\text { control }\end{array}$ & .134 & 31 & .150 \\
\hline
\end{tabular}

Terlihat bahwa untuk semua kelompok signifikansi pada uji Kolmogorov-Smirnov lebih besar dari 0,05. Dengan demikan maka semua sebaran data berdistribusi normal.

\section{Uji Homogenitas}

Uji homogenitas varian di lakukan dengan pengelompokan berdasarkan model pembelajaran, yaitu model pembelajaran kooperatif tipe Numbered Head Together (NHT) dengan model pembelajaran konvensional. Yang digunakan adalah Levene's Test Of Equality Error Variance. kriteria pengujian yang di gunakan adalah terima $H_{0}$ jika nilai $p>0,05$ dimana data memiliki varians yang sama apabila angka signifikansi yang di hasilkan lebih dari 0,05.

Tabel 3

\section{Rangkuman Hasil Uji Homogenitas Varians menggunakan Levene's Test of Equality of Error Variances ${ }^{a}$}

\begin{tabular}{rrrrrr}
\hline Levene Statistic & $\mathrm{df1}$ & & $\mathrm{df2}$ & & Sig. \\
\hline 0.395 & & 1 & & 51 & .533 \\
\hline
\end{tabular}

Berdasarkan hasil penelitian taraf signifikansi lebih besar dari >0,05. Sehingga dapat di simpulkan bahwa variansi pada setiap kelompok adalah sama (homogen).

\section{Uji Hipotesis}

Pengujian hipotesis menggunakan uji- $t$ karena variansi normal dan homogen, maka di pilih parametric.

Berdasakan hasil penelitian diketahui bahwa $p<0,05$, karena nilai signifikasinya adalah 0,016 yang berarti 0,016 lebih rendah dari 0,05 . Hal ini menyatakan bahwa terdapat perbedaan hasil belajar teknik dasar passing atas dan passing bawah antara peseta didik yang di beri perlakuan dengan model pembelajaran kooperatif tipe NHT dengan peserta didik yang di beri perlakuan dengan model pembelajaran konvensional. Sehingga model pembelajaran kooperatif tipe NHT berpengaruh signifikan terhadap hasil belajar teknik dasar passing atas dan passing bawah bola voli pada peserta didik kelas XI SMA PGRI Seririt.

\section{Pembahasan}


Berdasarkan hasil analisis data di peroleh bahwa terdapat perbedaan hasil pembelajaran antara peserta didik yang belajar dengan model pembelajaran kooperatif tipe NHT dengan model pembelajaran tipe konvesional. Berarti model pembelajaran kooperatif tipe NHT berpengaruh signifikan terhadap hasil belajar peserta didik di XI SMA PGRI Seririt teknik dasar pssing bola voli. Pada penelitian ini masing-masing kelompok di berikan perlakuan yang berbeda, dimana kelompok eksperimen di berikan perlakuan berupa model pembelajaran kooperatif tipe NHT sedangkan pada kelompok kontrol di berikan perlakuan model pembelajaran konvensional. Pendekatan ini di rancang untuk mengembangkan indikator-indikator kunci pembelajaran kooperatif yang meliputi saling ketergantungan positif, tanggung jawab perseorangan, dan partisipasi yang merata. Dalam pendekatan struktural, tujuan kognitif yang hendak dicapai adalah berupa informasi akademik sederhana, sedangkan tujuan sosialnya adalah keterampilan kelompok dan keterampilan sosial. Struktual tim beranggotakan 3-5 orang tiap kelompok.

Dalam pembelajaran kelompok kontrol yang di belajarkan menggunakan model pembelajaran konvensional menekankan pada guru sebagai pusat informasi dan peserta didik sebagai penerima informasi. Situasi kelas sebagian besar masih berfokus pada guru sebagai sumber utama pengetahuan, serta pengguanaan model ceramah sebagai pilihan utama strategi belajar mengajar. Pembelajaran di kelompok kontrol di lakukan dengan model ceramah oleh guru dalam penyampaian materi kemudian mendemonstrasikan materi pelajaran dan menugaskan siswa untuk mempraktikkan materi yang di ajarkan. Melalui penugasan tersebut diharapkan siswa mampu memahami dan melakukan gerakan dengan benar.

Berdasarkan pengamatan peneliti pada saat pembelajaran berlangsung di kelompok eksperimen, pembelajaran diarahkan untuk memberikan perhatian dan pemahaman peserta didik tentang materi teknik dasar passing bola voli dalam mengikuti pembelajaran Trianto (2007: 82) yang menyattakan bahwa pembelajaran dengan metode kooperatif tipe NHT di susun untuk memudahkan siswa dalam memahami materi pelajaran dan mengecek pemahaman siswa terkait isi pelajaran.

Sejalan dengan penelitian yang di lakukan Kadek Satriawan meneliti pengaruh penerapan model pembelajaran kooperatif tipe numbered head together terhadap hasil belajar teknik dasar passing bola voli terhadap hasil belajar siswa kelas X SMA Laboratorium Undiksha Singaraja tahun pelajaran 2016/2017 menemukan hasil belajar yang signifikan antara siswa kelas $X$ yang di ajar dengan metode ceramah (kelas control) dengan hasil belajar siswa kelas $X$ yang di ajar. Dengan metode tipe NHT, hal yang tersebut terbukti dengan hasil perhitungan uji-t di peroleh 0,05 dan analisis dengan uji-t di peroleh signifikan = $0,000(p<0,05)$ sehingga hipotesis diterima dan perolehan rata - rata kelas eksperimen lebih tinggi dari pada kelas Kontrol (0,204 > $0,352)$. Dengan demikian penerapan metode pembelajaran NHT Memberikan pengaruh yang baik terhadap hasil belajar siswa.

Berdasarkan pengamatan peneliti pada saat pembelajaran berlangsung, model konvesional yang di terapkan oleh kelompok control pada dasarnya menuntun peserta didik untuk dapat memahami dan mempraktikan gerakan dengan benar tapi masih mengunakan metode ceramah dalam penyampaiaan materi pelajaran yang berpusat pada guru dan masih banyak siswa kurang aktif. Hal ini kurang mengakibakan partisipasi peserta didik secara menyeluruh dalam proses belajar mengajar atau peserta didik yang memiliki kemampuan yang lebih yang aktif dalam proses pembalajaran, sehingga pemahaman dan keterampilan peserta didik dalam melakukan teknik dasar passing bola voli menjadi terhambat dan tidak rata. Sedangkan hal ini berbeda dengan kelompok ekperimen yang menggunakan model pembalajaran kooperatif tipe NHT yang di maksud dalam penelitian ini adalah model pembelajaran mengorganisasikan siswa dalam kelompok kecil dari jumlah 52 peserta didik yang di bagi menjadi 11 kelompok, dimana 8 kelompok ada 5 peserta didik dan 3 kelompok ada 4 peserta 
didik yang memiliki kemampuan berbeda (heterogen), guru mengajukan pertanyaan kepada tiap-tiap kelompok dan setiap kelompok berpikir bersama dalam kelompoknya, kemudian peserta didik di tunjuk secara acak untuk mempersentasikan hasil diskusi kelompok di depan sedangkan anggota kelompok lain tidak boleh membantu temannya, kemudian guru memberikan evaluasi pembelajaran dan memberikan penghargaan.

Dari hasil analisis data di atas memberikan gambaran bahwa model pembelajaran kooperatif tipe NHT dalam pembelajaran teknik dasar passing bola voli berpengaruh signifikan terhadap hasil belajar peserta didik. Hasil penelitian ini memberikan implikasi bahwa terdapat perbedaan hasil belajar teknik dasar passing bola voli antara peserta didik yang dibelajarkan menggunakan model pembelajaran kooperatif tipe NHT dengan peserta didik yang di belajarkan dengan menggunakan model pembelajaran konvensional.

\section{Implikasi}

Implikasi yang di timbulkan dengan adanya pengaruh penerapan Model Pembelajaran Kooperatif Tipe NHT terhadap Hasil Belajar PJOK adalah sebagai berikut :

1. Pembelajaran menggunakan tipe NHT mendorong peserta didik menjadi lebih aktif dalam mengikuti kegiatan pembelajaran dibandingkan dengan sebelum menggunakan model pembelajaran tipe NHT.

2. Adanya kerjasama antarpeserta didik yang mendorong peserta didik untuk saling peduli.

3. Peserta didik menjadi lebih percaya diri tampil di depan peserta didik lain

4. Munculnya motivasi dan minat peserta didik dalam mengikuti kegiatan pembelajaran PJOK.

\section{SIMPULAN DAN SARAN Simpulan}

Hasil belajar yang rendah dan belum tercapainya ketuntasan belajar secara menyeluruh berdasarkan nilai observasi awal pada siswa kelas XI SMA PGRI Seririt, mendorong peneliti untuk melakukan suatu penelitian agar menghasilkan hasil belajar yang lebih baik. Hasil belajar yang rendah adanya suatu faktor yaitu guru masih menggunakan model pembelajaran yang konvensional.

Model pembelajaran kooperatif tipe NHT menjadi solusi yang di tawarkan peneliti untuk meningkatkan hasil belajar siswa di karenakan melalui penerapan model pembelajaran kooperatif tipe NHT dengan maksud membantu kesulitan guru dalam memberikan materi pembelajaran kepada peserta didik. Dalam pembelajaran ini peserta didik ditempatkan dalam kelompok-kelompok kecil yang beranggotakan 3 sampai 5 peserta didik yang heterogen. Dengan demikian peneliti mengadakan penelitian dengan judul Pengaruh Model Pembelajaran Kooperatif Tipe Numbered Head Together (NHT) Terhadap Hasil Belajar Teknik Dasar Passing Bola Voli Pada Peserta Didik Kelas XI SMA PGRI Seririt Tahun Pelajaran 2019/2020.

Berdasarkan hasil analisis data dan pembahasan maka dapat disimpulkan bahwa model pembelajaran kooperatif tipe NHT berpengaruh signifikan terhadap hasil belajar teknik dasar passing bola voli pada peserta didik kelas XI SMA PGRI Seririt.

\section{Saran}

Adapun saran yang dapat di sampaikan berdasarkan hasil penelitian yang telah di laksanakan adalah sebagai berikut.

1. Bagi guru PJOK model pembelajaran kooperatif tipe NHT dapat dijadikan salah satu alternatif model pembelajaran yang dapat di terapkan di lapangan untuk membangun keaktifan peserta didik pada pembelajaran Pjok mengingat memberikan pengaruh positif terhadap hasil belajar peserta didik.

2. Bagi peneliti lain yang tertarik meneliti permasalahan ini, di sarankan untuk meneliti variabel terikat lain, menggunakan materi yang lain dengan memperhatikan kendala-kendala yang telah dihadapi oleh peneliti selama penelitian. 


\section{DAFTAR RUJUKAN}

Ari Darmika, I Komang. Model Kooperatif Tipe NHT Untuk Meningkatkan Hasil Belajar Teknik Dasar Passing Bola Voli Pada Siswa Kelas VII di SMP 3 Singaraja. Tersedia Pada http://ejournal.undiksha.ac.id/index.p hp/iip. Diakses pada tanggal 19 febuari 2018.

Danu Budhiarta, I Made. 2008. Buku Ajar Permainan Bola Voli Dan Bola Voli Pantai. Jurusan Pendidikan Jasmani Kesehatan dan Rekreasi, Fakultas Olahraga dan Kesehatan, Universitas Pendidikan Ganesha Singaraja.

Dimiyati dan Mudjiono. 2006. Belajar dan Pembelajaran. Jakarta: Rineka Cipta.

Gunadi, I Gusti Putu Putra , I Putu Panca Adi, Putu Adi

Suputra.2017.Pengaruh Model Pembelajaran Kooperatif Tipenht Terhadap Hasil Belajar Teknik Dasar Passing Bola Voli. Jurusan Pendidikan Jasmani Kesehatan dan Rekreasi, Fakulatas Olahraga dan Kesehatan, Universitas Pendidikan Ganesha Singaraja. .E-Journal PJKR, Universitas Pendidikan Ganesha Pendidikan Jasmani, Kesehatan, dan Rekreasi (Vol 8, No.2, Tahun 2017). https://ejournal.undiksha.ac.id/index. php/JJP/article/view/13080. Diakses tanggal 08 Mei 2020.

Kanca, I Nyoman. 2010. Metodologi Penelitian Pengajaran Pendidikan Jasmani dan Olahraga. Singaraja : Universitas Pendidikan Ganesha.

Ma'mun, Amung. 2001. Pendekatan Keterampilan Taktis dalam

Trianto. 2007. Model-Model Pembelajaran Inovatif Berorientasi Konstruktif. Jakarta: Prestasi Pustaka Publisher.

Universitas Pendidikan Ganesha. 2016. Pedoman Penulisan Karya IImiah Tugas Akhir, Skripsi, Tesis, dan Disertasi. Singaraja.

Yoga Permana, Asepta. 2008. Bola Volley. Surabaya: Insan Cendekia
Pembelajaran Bola Voli. Jakarta. Departemen Pendidikan Nasional. Derektorat Jenderal Pendidikan Dasar dan Menengah.

Permendiknas. 2007. Standar Proses Untuk satuan Pendidikan Dasar Dan Menengah. Jakarta. Depdiknas.

Puja, Nyoman, I Wayan Rai, I Made Satyawan.2017. Pengaruh Penerapan Model Pembelajaran Kooperatif Tipenumbered Head Togetherterhadap Hasil Belajar Teknik Dasarpassing Bola Voli. Jurusan Pendidikan Jasmani Kesehatan dan Rekreasi, Fakultas Olahraga dan Kesehatan, Universitas Pendidikan Ganesha ,Singaraja. E_Journal Pendidikan Jasmani, Kesehatan dan RekreasiFakultas Olahraga dan Kesehatan, Undiksha, Volume 8, Nomor 2 (2017). https://ejournal.undiksha.ac.id/index. php/JJP/article/viewFile/14803/9070. Diakses tanggal 08 Mei 2020.

Rusman. 2012. Model-Model Pembelajaran. Jakarta: PT Raja Grafindo Persada

Slavin, E Robert. 2010. Cooperative Learning: Teori, riset dan Praktek. Bandung: Nusa Media.

Suryosubroto, B. 2009. Proses Belajar Mengajar Di Sekolah Edsisi Revisi. Jakarta: PT Rineka Cipta.

Satriawan Kadek. Model Kooperatif Tipe NHT Untuk Meningkatkan Hasil Belajar Teknik Dasar Passing Bola Voli Pada Siswa Kelas X di SMA Laboratorium Undiksha Singaraja. Tersedia Pada http://ejournal.undiksha.ac.id/index.p hp/ijp. Diakses pada tanggal 19 Febuari 2018. 